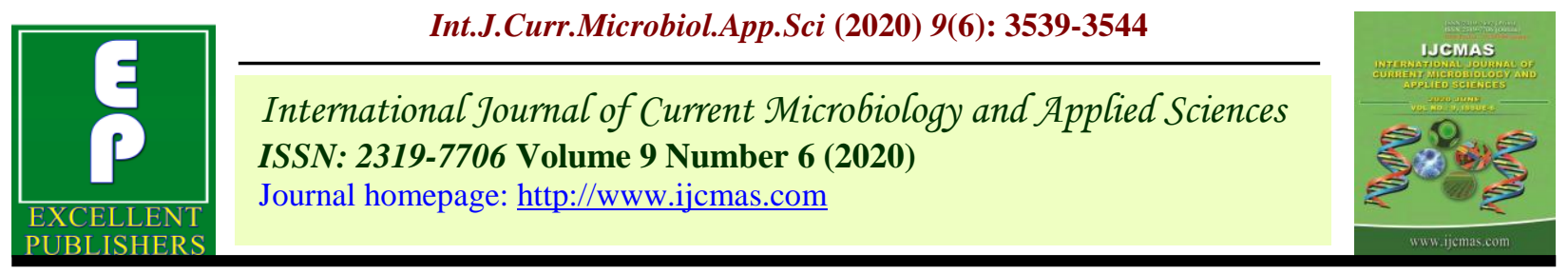

Original Research Article

https://doi.org/10.20546/ijcmas.2020.906.416

\title{
A Study on Perception of Farmers Interest Group (Fig) Members towards its Functioning in Bengaluru Urban District, India
}

\author{
R. Puneeth Raja*, M. Shivamurthy and Manjuprakash \\ Department of Agricultural Extension, \\ University of Agricultural Sciences, GKVK, Bangalore - 560065, India \\ *Corresponding author
}

\begin{tabular}{|l|}
\hline Ke y w o r d s \\
Concept, \\
$\begin{array}{l}\text { Empowered and } \\
\text { strengthened }\end{array}$ \\
\hline Article Info \\
\hline $\begin{array}{l}\text { Accepted: } \\
\text { 26 May 2020 } \\
\text { Available Online: } \\
\text { 10 June } 2020\end{array}$ \\
\hline
\end{tabular}

\section{A B S T R A C T}

Farmers' Interest Group (FIG) is a group approach concept under Farmers' Produce Organisation (FPO). FPOs are running successfully helping fellow farmers in gaining more profit by means of collective purchasing and bulk selling of their produce. In this backdrop the study was conducted in Anekal taluk of Bengaluru urban district of Karnataka during 2019, in order to study the perception of the members of the FIG towards it functioning. 12o farmer members of the FIG were interviewed personally and it was found out that, less than half $(40.83 \%)$ of the respondents had better perception followed by equal proportion i.e., 30.00 and 29.16 per cent of them had average and poor perception respectively towards functioning of FIG. FIGs should be strengthened in order to empower farmers.

\section{Introduction}

Group approaches such as Farmers' Organisations, Farmers Clubs, Farmers' Interest Groups etc., are gaining very much importance in the recent past. The bringing of all small and marginal farmers of similar goals and interest should be brought under same umbrella to maximise the efficiency and effectiveness of farming in the country. Over the years countries farmers have found that they can increase their income and efficiency by joining with other farmers to market their goods, purchase their inputs and co-ordinate their farming techniques (Robbins et. al., 2005). Farmers Interest Group (FIG) is a selfmanaged, independent group of farmers with a shared goal and interest.

The members work collectively to achieve the set goals by amalgamating their prevailing resources, achieving better access to other resources and to share in the resulting benefits. FIGs are formed under every Farmer Producer Organisation (FPOs) in order to smooth conduct of the mandates and the 
objectives set before formation of FPO. In this backdrop an effort was made to study the perception of the members of the FIGs towards its performance.

\section{Materials and Methods}

\section{Locale of the study}

The study was conducted in Anekal taluk of Bengaluru urban district of Karnataka during 2019. Anekal is $36 \mathrm{~km}$ from Bangalore centre and around $15 \mathrm{~km}$ from Hosur. The connectivity of express line such as National Highway and State Highway runs between the Anekal and silk board.

\section{Selection of respondents for the study}

The name and addresses of all the members of 12 FIGs were collected from the record maintained at Anekal Horticulture Farmer Producer Company (FPC) limited, Anekal. From Anekal taluk six Gram Panchayats were selected randomly for the study, further two FIGs from each panchayat were selected purposively and ten FIG members from each of the FIGs were selected by applying simple random sampling technique. Thus forming a total of 120 respondents and the data was collected using personal interview method.

\section{Research design}

Ex-post facto research design was used for the study and hence, variables studied are already occurred and therefore could not be manipulated by the researcher (Table 1).

\section{Operational definition of perception of FIG members}

Perception of farmers about the functioning of farmers interest groups

Perception of farmer member about the working of FIGs in the current study refers to the interpretation of farmers' perception on general conduct of FIGs, services provided by FIGs to the member farmers and extension activities carried by FIGs for strengthening of its members.

Van Den Ban and Hawkins (1988) opined that, perception is the process by which we relate information or stimuli from our environment and transform it into psychological awareness.

\section{Results and Discussion}

\section{Perception of member towards functioning} of farmers interest group

The results pertaining to the perception of members about the functioning of Farmers Interest Groups are presented in Table 2, Table 3, and Table 4. The perception of the members about the functioning of FIGs was studied by considering three aspects viz., general aspects of FIGs, services provided at FIGs and extension activities conducted by FIGs.

Perception of members towards general aspects of FIGs

The perception of members with respect to general aspects of FIGs (Table 2), it was found that the statement 'group meeting of FIG was helpful in updating required agricultural information' was ranked first, as group meeting was organised for discussion of the current problems that the farmer members were facing, hence it secured the first rank, followed by CEO of Farmers Producer Company also manages the FIG (Rank II) since, the FIG were formed very recently and the leaders of FIG had less experience of running the FIG so CEO of FPC also involved in managing the FIGs of the study area. FIG ensures optimal production planning through self-help approach (Rank III), FIG was unable to cater 
the needs of all the members of FIG (Rank IV) this was experienced by the members because they were growing varieties of vegetables and sometimes FIG failed to provide critical inputs at right time.

FIG provided a forum for interface with public and private technology and inputs (Rank V) in order to help members increase their productivity and it also tried to identify the best quality seeds, fertilizers etc., from private companies rather than only relaying on subsidized inputs given by the government. FIG acted as collateral for loans availed from FPC (Rank VI) as it is evident that the member farmers belonged to BPL family hence, FIG helped its members to avail the loan as the members had nothing to keep as collateral for the loan. FIG manages the revolving fund for group activities, identifying technical and product opportunities (Rank VII) but the same fund was not sufficient to provide short term loan to the members.

\section{Perception of members about service provided at FIGs}

With respect to the perception of members towards the services provided at FIGs (Table 3 ), it was observed that 'FIG supplied the required inputs to the member farmers was ranked first, this might be because of the reason that, the main objective of any FIG is to purchase the necessary inputs in bulk and supply the same to its members at the wholesale price. Followed by seed banking, processing facility and market information were the useful FIG innovation (Rank II) since the members were growing vegetables and in order to increase the yield but FIGs failed in helping its members with regard to value addition but it was mentioned by the manager of FPC that they will soon start the processing unit.
Capacity building programme conducted helped the farmers to equip with the required skills (Rank III) the newer technologies might be of opinion among the members that they were complex to use and understand hence, the capacity building programs helped to overcome the same problems. Technical guidance provided by FIGs has enhanced crop productivity (Rank IV) because the information provided by FIG was helpful in taking proper decisions at a right time. Marketing information provided by FIG improved the bargaining power of members (Rank V) as it helped the members to sell their produce in the market where they could fetch more returns. The technologies suggested by FIG had reduced drudgery among farmers (Rank VI) as FIG suggested the more appropriate and time saving technologies. Fund mobilization and Credit linkage for FIG's helps in maintaining the stable financial condition of the members (Rank VII) because it linked with the formal sources of credit. FIG provided the Forward linkage facility and helped in assured market for the member farmers (Rank VIII) because FIG had not yet linked any of the members to the marketing and processing i.e. forward linkage. This might be because of the reason that, here FIGs played an important role in providing the better quality inputs at lower prise as compared to any other input company to FIG members in order to minimize the cost of production as well as in increasing the production, hence 'FIG supplied the required inputs to the member farmers' was quoted by the members as first rank.

\section{Perception of members about extension activities conducted by FIGs}

With respect to the perception of members about extension activities of FIGs (Table 4), it was found that the statement 'Exposure visits arranged by FIG had improved behaviour towards improved 
agricultural technologies secured first rank this might be because of the reason that, it improved their adopting capacity of the members.

Followed by capacity building programmes organised by FIG to its members had improved their skills (Rank II) as the technical knowledge of the particular technology was necessary and it can only be enhanced by the capacity building programmes. Result demonstration conducted by the FIGs had resulted in better understanding the value/worth of new technology (Rank III) this might be because of the reason that it helped in making the members to understand the worth of new technology. Farmer Field Schools (FSS) conducted by FIG had fascinated the members to adopt the new technologies (Rank IV) and extension personnel conducts field visits to members of FIG (Rank V) because of the lack of fund FIG could organise only few of the visits.

Table.1 Details of Farmer Interest Groups and sample size selected for the study

\begin{tabular}{|c|c|c|c|}
\hline $\begin{array}{l}\text { Sl. } \\
\text { No. }\end{array}$ & $\begin{array}{c}\text { Name of gram } \\
\text { panchayat }\end{array}$ & Name of FIGs & $\begin{array}{c}\text { No of } \\
\text { respondents selected }\end{array}$ \\
\hline \multirow[t]{2}{*}{1} & \multirow[t]{2}{*}{ Samandhuru } & Samandhuruthotagarikebelegarara sangha & 10 \\
\hline & & Karagadammathotagarikebelegarara sangha & 10 \\
\hline \multirow[t]{2}{*}{2} & \multirow[t]{2}{*}{ Balluru } & Kodalipurathotagarikebelegarara sangha & 10 \\
\hline & & Bhasaveshwarathotagarike belegarara sangha & 10 \\
\hline \multirow[t]{2}{*}{3} & \multirow[t]{2}{*}{ Karpuru } & Sri Rama thotagarikebelegarara sangha & 10 \\
\hline & & Karpuruthotagarikebelegarara sangha & 10 \\
\hline \multirow[t]{2}{*}{4} & \multirow[t]{2}{*}{ Mayasandra } & Mayasandrathotagarikebelegarara sangha & 10 \\
\hline & & Manchanahallithotagarikebelegarara sangha & 10 \\
\hline \multirow[t]{2}{*}{5} & \multirow[t]{2}{*}{ Byagadadenahalli } & Koonmadivalathotagarikebelegarara sangha & 10 \\
\hline & & Soppallithotagarikebelegarara sangha & 10 \\
\hline \multirow[t]{3}{*}{6} & \multirow[t]{2}{*}{ Hennagara } & Hennagarathotagarikebelegarara sangha & 10 \\
\hline & & Yellammadevithotagarikebelegarara sangha & 10 \\
\hline & \multicolumn{2}{|r|}{ Total } & 120 \\
\hline
\end{tabular}

Table.2 Perception of members about general aspects of FIGs $(n=120)$

\begin{tabular}{|c|c|c|c|c|c|c|c|c|c|}
\hline \multirow{2}{*}{$\begin{array}{l}\text { Sl. } \\
\text { No. }\end{array}$} & \multirow{2}{*}{ Perception statements } & \multicolumn{2}{|c|}{ Agree } & \multicolumn{2}{|c|}{ Undecided } & \multicolumn{2}{|c|}{ Disagree } & \multirow{2}{*}{$\begin{array}{l}\text { Mean } \\
\text { score }\end{array}$} & \multirow{2}{*}{ Rank } \\
\hline & & f & $\%$ & $\mathbf{f}$ & $\%$ & f & $\%$ & & \\
\hline 1 & $\begin{array}{l}\text { Group meeting of FIG is helpful in updating required } \\
\text { agricultural information }\end{array}$ & 116 & 96.6 & 2 & 1.66 & 2 & 1.66 & 2.95 & I \\
\hline 2 & CEO of Farmers Producer Company also manages the FIG & 114 & 95 & 3 & 2.5 & 3 & 2.5 & 2.92 & II \\
\hline 3 & $\begin{array}{l}\text { FIG ensures optimal production planning through self-help } \\
\text { approach }\end{array}$ & 105 & 87.5 & 13 & 10.8 & 2 & 1.66 & 2.85 & III \\
\hline 4 & FIG is unable to cater the needs of all the members of FIG & 13 & 10.8 & 27 & 22.5 & 80 & 66.6 & 2.55 & IV \\
\hline 5 & $\begin{array}{l}\text { FIG provides a forum for interface with public and private } \\
\text { technology and inputs }\end{array}$ & 45 & 35.8 & 37 & 30.8 & 40 & 33.3 & 2.025 & V \\
\hline 6 & FIG act as collateral for loans availed from FPC & 0 & 0 & 38 & 31.6 & 82 & 68.3 & 1.31 & VI \\
\hline 7 & $\begin{array}{l}\text { FIG manages the revolving fund for group activities, } \\
\text { identifying technical and product opportunities }\end{array}$ & 1 & 0.83 & 17 & 14.1 & 102 & 85 & 1.15 & VII \\
\hline
\end{tabular}


Table.3 Perception of members about service provided at FIGs $(n=120)$

\begin{tabular}{|c|c|c|c|c|c|c|c|c|c|}
\hline \multirow{2}{*}{$\begin{array}{l}\text { Sl. } \\
\text { No. }\end{array}$} & \multirow[t]{2}{*}{ Perception statements } & \multicolumn{2}{|c|}{ Agree } & \multicolumn{2}{|c|}{ Undecided } & \multicolumn{2}{|c|}{ Disagree } & \multirow{2}{*}{$\begin{array}{l}\text { Mean } \\
\text { score }\end{array}$} & \multirow[t]{2}{*}{ Rank } \\
\hline & & f & $\%$ & $\mathbf{f}$ & $\%$ & $\mathbf{f}$ & $\%$ & & \\
\hline 1 & $\begin{array}{l}\text { FIG supplies the required inputs to the } \\
\text { member farmers }\end{array}$ & 115 & 95.8 & 5 & 4.9 & 0 & 0 & 2.95 & I \\
\hline 2 & $\begin{array}{l}\text { Seed banking, processing facility and } \\
\text { market information are the useful FIG } \\
\text { innovation }\end{array}$ & 107 & 89.1 & 11 & 9.1 & 2 & 1.6 & 2.87 & II \\
\hline 3 & $\begin{array}{l}\text { Capacity building programme conducted } \\
\text { helps the farmers to equip with the } \\
\text { required skills }\end{array}$ & 102 & 85 & 7 & 5.8 & 11 & 9.1 & 2.75 & III \\
\hline 6 & $\begin{array}{l}\text { Technical guidance provided by FIGs has } \\
\text { enhanced crop productivity }\end{array}$ & 94 & 78.3 & 18 & 15 & 8 & 6.6 & 2.71 & IV \\
\hline 5 & $\begin{array}{l}\text { Marketing Information provided by FIG } \\
\text { improves the bargaining power of } \\
\text { members }\end{array}$ & 88 & 73.3 & 10 & 8.3 & 22 & 18.3 & 2.55 & V \\
\hline 4 & $\begin{array}{l}\text { The technologies suggested by FIG has } \\
\text { reduced drudgery among farmers }\end{array}$ & 83 & 69.1 & 18 & 15 & 19 & 15.8 & 2.53 & VI \\
\hline 7 & $\begin{array}{l}\text { Fund mobilization and Credit linkage for } \\
\text { FIG's helps in maintaining the stable } \\
\text { financial condition of the members }\end{array}$ & 02 & 1.66 & 23 & 19.1 & 95 & 79.1 & 1.22 & VII \\
\hline 8 & $\begin{array}{l}\text { FIG provides the Forward linkage facility } \\
\text { and helps in assured market for the } \\
\text { member farmers }\end{array}$ & 01 & 0.83 & 18 & 15 & 101 & 84.1 & 1.16 & VIII \\
\hline
\end{tabular}

Table.4 Perception of members about extension activities conducted by FIGs $(\mathrm{n}=120)$

\begin{tabular}{|c|c|c|c|c|c|c|c|c|c|}
\hline \multirow{2}{*}{$\begin{array}{l}\text { Sl. } \\
\text { No. }\end{array}$} & \multirow[t]{2}{*}{ Perception statements } & \multicolumn{2}{|c|}{ Agree } & \multicolumn{2}{|c|}{ Undecided } & \multicolumn{2}{|c|}{ Disagree } & \multirow{2}{*}{$\begin{array}{l}\text { Mean } \\
\text { score }\end{array}$} & \multirow{2}{*}{ Rank } \\
\hline & & f & $\%$ & $\mathbf{f}$ & $\%$ & $\mathbf{f}$ & $\%$ & & \\
\hline 1 & $\begin{array}{l}\text { Exposure visits has improved behaviour } \\
\text { towards improved agricultural technologies }\end{array}$ & 102 & 85 & 3 & 2.5 & 15 & 12.5 & 2.74 & I \\
\hline 2 & $\begin{array}{l}\text { Capacity building programmes by FIG to } \\
\text { the members has improved their skills }\end{array}$ & 101 & 84.1 & 7 & 5.83 & 12 & 10 & 2.7 & II \\
\hline 3 & $\begin{array}{l}\text { Result demonstration conducted by the } \\
\text { FIGs has resulted in better understanding } \\
\text { the value/worth of new technology. }\end{array}$ & 88 & 73.3 & 8 & 6.6 & 24 & 20 & 2.53 & III \\
\hline 4 & $\begin{array}{l}\text { FFS conducted by FIG has fascinated the } \\
\text { members to adopt the new technologies }\end{array}$ & 55 & 45.8 & 3 & 2.5 & 62 & 51.6 & 1.94 & IV \\
\hline 5 & $\begin{array}{l}\text { Extension personnel conducts field visits to } \\
\text { members of FIG }\end{array}$ & 65 & 38.3 & 9 & 7.5 & 65 & 54.1 & 1.84 & V \\
\hline
\end{tabular}




\section{Over all perception of farmers about} functioning of FIGs

The results depicted in the Table 5 reveals that less than half $(40.83 \%)$ of the respondents had a better perception about functioning of FIGs this might be because of the reason that, majority of the activities conducted by FIG were helpful in bringing desirable changes in all the operations followed by almost equal proportion $(30.00$ $\%)$ and $(29.16 \%)$ of the respondents had average and poor perception about functioning of FIGs respectively, the average and poor perception of the members was because of the fact that FIG had not established in full fledge and it also could not link the farmers with marketing and processing. Also majority of the respondents had high cosmopoliteness and medium level of extension contact and high level of social participation so that less than half of the members had better perception. The present findings are in line with the findings Rupesh et al., (2017).

The group approaches are helpful in uniting the farmers in crop production, purchase of the required critical inputs and sale of the produce in bulk. This will definitely have abundance of advantage to the farming community especially small and marginal farmers who will have less say in the market for bargaining. The FIGs should be established in all the villages across the country for various crops that are grown in the particular region so that the cost of production, transportation while purchasing of inputs and sale of the produce will be minimised. Thereby the farmers may be empowered.

\section{References}

Robbins P, Bikande F, Ferris S, Kleih U, Okoboi, and Wandschneider T., 2005, The territorial approach to rural agro-enterprise development, collective marketing for smallholder farmers, www.fao.org.

Rupesh Ranjan, Ansari, M. A., Verma, A. P., Shekhar, S. and Rashit, S., 2017, Farmers perception towards effectiveness of Krishi Vigyan Kendra: A Study in Uttarkhand, India.Int. J. Curr. Microbiol. App. Sci., 6 (3):878890

Van Den Ban, A. W., and H. S, Hawkins, 1988, Agriculture Extension, Longman Scientific and Technical.

\section{How to cite this article:}

Puneeth Raja, R., M. Shivamurthy and Manjuprakash. 2020. A Study on Perception of Farmers Interest Group (Fig) Members towards its Functioning in Bengaluru Urban District, India. Int.J.Curr.Microbiol.App.Sci. 9(06): 3539-3544. doi: https://doi.org/10.20546/ijcmas.2020.906.416 